\title{
Breeding period in the mangrove crab Goniopsis cruentata (Decapoda: Grapsidae) in Northeast Brazil
}

\author{
José Jonathas Pereira Rodrigues de Lira ${ }^{1}$, Tereza Cristina dos Santos Calado ${ }^{2} \&$
}

Marina de Sá Leitão Câmara de Araújo ${ }^{3}$

1. Universidade Federal do Ceará (UFC), Departamento de Biologia, Laboratório de Histologia e Reprodução Animal, Av. Humberto Monte, s/n, Campus do Pici, Pici, CEP 60455-900-Fortaleza, Ceará, Brazil; jose.jonathas@hotmail.com

2. Universidade Federal de Alagoas (UFAL), Laboratórios Integrados de Ciências do Mar e Naturais (LABMAR), Av. Aristeu de Andrade, 452, Farol, CEP 57051-090-Maceió, Alagoas, Brazil; terezacalado@hotmail.com

3. Universidade Federal de Pernambuco (UFPE), Departamento de Oceanografia (DOCEAN), Laboratório de Carcinologia (Labcarci), Av. Arquitetura, s/n, Cidade Universitária, CEP 50670-901-Recife, Pernambuco, Brazil; mslc.araujo@gmail.com

\section{Received 01-III-2012. C Corrected 03-VII-2012. Accepted 09-VIII-2012.}

\begin{abstract}
The brachyuran crabs are iteroparous species which present a high diversification of reproduction patterns, which may have evolved as a species-specific response to environmental conditions. Tropical species commonly present a year-round reproduction due to stable environment conditions. Goniopsis cruentata is a crab species widely distributed along the Western Atlantic, inhabiting practically every microhabitat in the mangrove ecosystem. The aim of the present study is to determine the breeding period of the crab Goniopsis cruentata in Northeastern Brazil and also to evaluate the influence of water salinity, rainfall and air and water temperature on it. A total of 71 ovigerous females, captured from August-2007 to July-2008, were used to assess the breeding period of this species. It was analyzed by the monthly proportion of ovigerous females. A correlation was applied to verify the influence of the abiotic factors on the breeding period. The present population bred seasonal-continuously with peaks in the dry period, which was not associated with monthly variations of salinity, rainfall and air and water temperatures. Therefore, according to statistical analyses, our hypothesis was refuted. However, breeding was intensified in the dry period, when salinity and temperatures were higher and rainfall was lower. We conclude that, even though breeding is not related to monthly variation of environmental factors, it occurs in periods of higher salinity and temperatures and lower rainfall. Rev. Biol. Trop. 61 (1): 29-38. Epub 2013 March 01.
\end{abstract}

Key words: life-history, reproduction, ovigerous females, environmental parameters, mangroves.

Reproduction is one of the most studied topics on life history of an organism (Stearns 1976, Stearns 2000). It is distinguished in two extreme strategies, semelparity and iteroparity (Cole 1954, Gadgil \& Bossert 1970, Stearns 1976, Bryant \& Hartnoll 1995). Among iteroparous organisms, the reproduction may be subdivided in two categories: 1) reproduction restricted to specific(s) period(s) of the year, known as seasonal iteroparity or seasonal reproduction or 2) continuous reproduction throughout the year, known as continuous iteroparity (Bell 1976, Sastry 1983, Pinheiro
\& Fransozo 2002, Negreiros-Fransozo et al. 2002, Litulo 2005). These iteroparity categories evolve in response to the survival of the offspring (Bell 1976). Therefore, seasonal iteroparity may emerge when the offspring experienced higher survival rates only in one, or more, periods of year, whereas continuous iteroparity is the strategy expected to occur when the offspring presents high rates of survival during the entire year.

Brachyuran crabs are iteroparous species which present a high diversification of reproduction patterns (Hartnoll \& Gould 1988), 
which may have evolved as a species-specific response to environmental conditions. Some of them, such as photoperiod, rainfall, lunar cycle, temperature, and food supply have proved to be strongly related to the reproductive period (Sastry 1983, Adiyodi 1988, Litulo 2005, Skov et al. 2005, Castiglioni \& Negreiros-Fransozo 2006). These factors (also known as extrinsic factors) act as signals of suitable and unsuitable periods for reproduction, whereas the physiological aspects (the intrinsic factors) are the interface between the organism and its environment (Zera \& Harshman 2001, Ricklefs \& Wikelski 2002). Both extrinsic and intrinsic factors trigger the ecdysis, mating and gonadal development (Sastry 1983) in order to overlap periods of high habitat quality for larval development (Boolootian et al. 1959, Sastry 1983, Cobo 2002a, Cobo 2002b).

Some authors have stated that the reproductive periodicity in Goniopsis cruentata (Latreille, 1803) (Grapsidae) follows a continuous pattern in subtropical mangroves (Silva \& Oshiro 2002, Cobo \& Fransozo 2003), region that present a well-known seasonal variation in environmental conditions. In these studies, however, ovigerous females did not occur in every month of collection effort. Therefore, reproduction is not completely aseasonal.
Mangroves are characterized by high salinity variation. This variation is due to tidal fluctuations (Hogarth 2007) and rainfall variations, both causing changes in salinity. Even though its effects are less pronounced in a latitudinal gradient than others, such as those from temperature and photoperiod (Sastry 1983), salinity is an important factor regulating biological activity in estuarine areas (Álvarez \& Ewald 1990).

The aim of the present study is to evaluate the breeding period of the crab Goniopsis cruentata in Northeastern Brazil and also the influence of water salinity, pluviosity and air and water temperature on it.

\section{MATERIAL AND METHODS}

Study site and species: The study was performed in the Mundaú/Manguaba Esturine Complex (Fig. 1), City of Maceió, State of

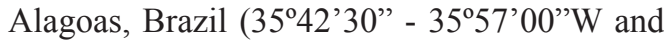
$9^{\circ} 35^{\prime} 00^{\prime \prime}$ - 9 $9^{\circ} 45^{\prime} 00^{\prime \prime}$ ) (Calado \& Sousa 2003). The climate is tropical, with an annual mean temperature of $25^{\circ} \mathrm{C}$ from 2000 to 2006 , and an annual mean rainfall of $1504 \mathrm{~mm}^{3}$ from 1998 to 2008 . These data were provided by the Secretaria de Estado do Meio ambiente e dos Recursos hídricos-SEMARHN, state of

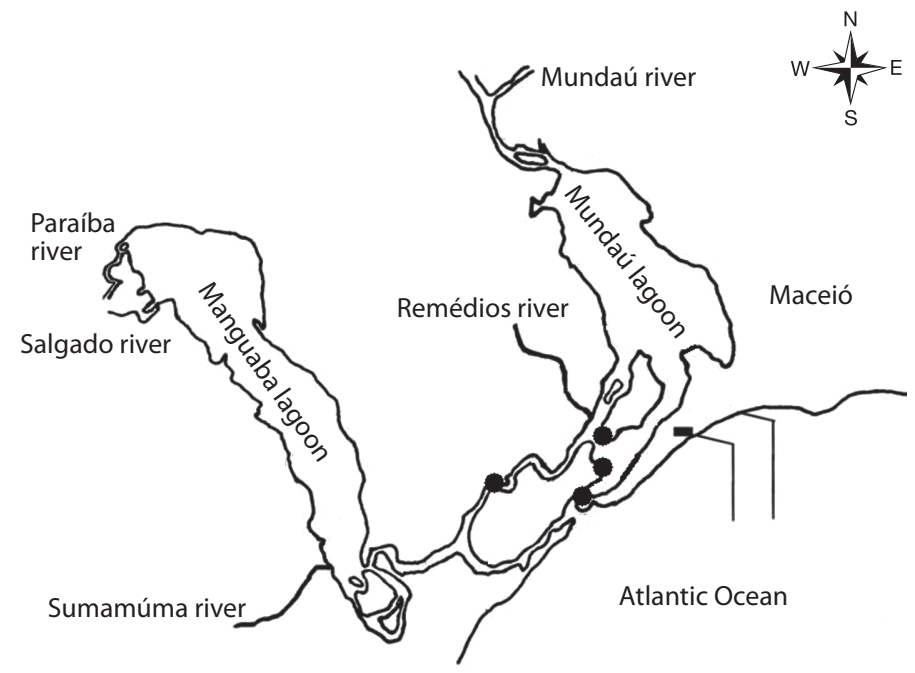

Fig. 1. Study area indicating the sampling sites, Mundaú/Manguaba Esturine Complex, Maceió, Alagoas, Brazil. 
Alagoas, Brazil. The area presents two welldefined seasons, the rainy season, from March to August, and the dry season, from September to February (Eskinazi-Leça 1976, Calado \& Sousa 2003, Araújo \& Calado 2008). From 1965 , the lowest values of salinities always occur during the rainy period with values as lower as 2. In the canals, salinities are often around 28, and near the outfall closely to 37 (Calado \& Sousa 2003). Marques (2001) designated the area as an eco-complex for the presence of estuaries, lagoons, mangroves, rivers, tropical forests, dunes, and sandbars. The species Goniopsis cruentata is a mangrove crab typically found wandering on the substratum above the tide level, in burrows of other crabs crevices and climbing in mangrove trees, practically occupying every microhabitat in the mangrove ecosystem (Cobo \& Fransozo 2003). According to Melo (1996), the distribution of G. cruentata ranges from Bermudas to Brazil (Western Atlantic), and from Senegal to Angola (Eastern Atlantic), also occurring in the Panama Pacific coast (Abele \& Kim 1989).

Field procedures: Samplings were monthly accomplished from August-2007 to July-2008 in four areas (Fig. 1), to maximize the number of collected individuals, by three collectors during 50 minutes in each region. These regions were chosen taking into account the accessibility and the abundance of the species. For the statistical analysis, however, the data were grouped, since there was no difference among the sampling stations according to previous statistical tests. Therefore, the collected crabs were considered as a unique population. The crabs were manually captured during full moon diurnal tides, starting during the ebb and finishing at the flood tide. Air and water temperature were measured with a toluene thermometer. Samples of water from the lagoons were obtained at the margin of the mangrove of each station, for salinity measurement. These procedures were accomplished before crab catching effort. In April-2008 there was no collection for reasons beyond control. The rainfall data to the studied period were provided by the SEMARHN.

Laboratory procedures: The salinity measurement was done in the hydrochemistry laboratory of the Federal University of Alagoas, Brazil. The captured crabs were sexed by abdomen morphology, being triangular shaped in the males and round shaped in the females. The female crabs had their carapace width measured by a Vernier calliper (precision of $0.05 \mathrm{~mm}$ ) and the egg-bearing condition was recorded to assess the breeding period of the species, following the classification proposed by Pinheiro \& Fransozo (2002). The egg stage of development was established as a way to infer the optimal time for spawning. Hence, the embryonic development was determined in two stages, according to Okamori \& Cobo (2003): (1) initial stage, when there was no sign of cleavage or cellular differentiation, and egg totally filled with yolk; (2) final stage, when the embryo is fully differentiated, with clear segmentation of limbs and well-developed eyes. The breeding period was assessed by the monthly proportion of ovigerous females in relation to total females. To test the association between the monthly proportions of ovigerous females in relation to the total females with the rainfall, and the mean values of water salinity and air and water temperature, multiple regression analysis were performed. This proportion was arc-sin transformed to meet the assumptions of Zar (1999). The rainy and dry periods were defined a priori, based on Eskinazi-Leça (1976). Among rainy and dry periods (as defined a priori), the absolute frequency of ovigerous was compared by applying a chisquare test $\left(\chi^{2}\right)$. Salinity, rainfall and air and water temperature were compared among these two periods by a Kruskall-Wallis ANOVA. Each statistical test was performed using the program Statistica 7.0, with a significance level of $5 \%$. The tests were applied after normality analysis of the data. 


\section{RESULTS}

A total of 554 females were captured, being 71 ovigerous females. The ranged from 22.45 to 42.45 , with a mean size of $31.85 \pm 4.80$. The number of the total females and the percentage of the ovigerous females in each month are shown in the table 1 . The ovigerous females were recorded almost all over the year, with higher proportions from December-2007 to March-2008 and they were not found in August and October-2007 and May-2008 (Fig. 1). From the 71 egg-bearer females collected, $76 \%$ were incubating eggs in initial stage and $24 \%$ in final stage of development, the majority of the latter occurring from November to December-2007.

The salinity ranged from 0.53 to 27.75 , with a mean of $17.40 \pm 8.5$. The lower water temperature was $19.88^{\circ} \mathrm{C}$, the highest $29.13^{\circ} \mathrm{C}$, with mean of $26.19 \pm 2.91$. The temperature ranged from $19.5^{\circ} \mathrm{C}$ to $30.63^{\circ} \mathrm{C}$, with a mean of $26.45 \pm 3.23$. The monthly rainfall varied from 5.4 to $569 \mathrm{~mm}^{3}$, with mean of 173.89 \pm 184.97 . No association between the monthly proportion of ovigerous females and the analyzed environmental parameters was observed $\left(\mathrm{F}_{4,6}=0.67, \mathrm{p}>0.05\right)$ (Fig. 1). A higher

TABLE 1

Monthly changes in the total number of females and egg bearer females of Goniopsis cruentata in the the Mundaú/Manguaba Estuarine Lagunar Complex, Maceió, Alagoas, Brazil

\begin{tabular}{clccc}
2007 & Mear & $\begin{array}{c}\text { Total } \\
\text { females }\end{array}$ & $\begin{array}{c}\text { Total } \\
\text { ovigerous } \\
\text { females }\end{array}$ & $\begin{array}{c}\text { Egg-bearer } \\
\text { females (\%) }\end{array}$ \\
& Aug & 65 & 0 & 0 \\
& Sep & 55 & 9 & 16.36 \\
& Oct & 61 & 0 & 0 \\
& Nov & 60 & 5 & 8.33 \\
& Dec & 49 & 14 & 28.57 \\
& Jan & 53 & 18 & 33.96 \\
& Feb & 53 & 10 & 18.86 \\
& Mar & 59 & 11 & 18.64 \\
& May & 37 & 0 & 0 \\
& Jun & 39 & 1 & 2.56 \\
& Jul & 23 & 3 & 13.04 \\
\hline
\end{tabular}

frequency of ovigerous females was found during the dry period (from September to February) $\left(\chi^{2}=4.2\right.$, d.f $\left.=1, p=0.04\right)$, in which were observed higher salinity $\left(\mathrm{H}_{1,11}=4.80, \mathrm{p}=0.029\right)$, water $\left(\mathrm{H}_{1,11}=4.03, \mathrm{p}=0.044\right)$ and air temperatures $\left(\mathrm{H}_{1,11}=4.03, \mathrm{p}=0.044\right)$ and lower rainfall $\left(\mathrm{H}_{1,11}=7.5, \mathrm{p}=0.006\right)$. Salinity and rainfall presented significant oscillations during the sampling period, as it can be seen in figure $2 \mathrm{~A}$ and B, while temperature was stable (Fig. 2C).

\section{DISCUSSION}

The ovigerous females of $G$. cruentata occurred throughout the year with a peak in the dry period. Therefore, the present population followed a seasonal-continuous breeding, according to the classification of Pinheiro \& Fransozo (2002). A continuous breeding season guarantees a year-round larvae supply, ensuring a continuous recruitment pattern to the population (Díaz \& Conde 1989, Negreiros-Fransozo et al. 2002, Litulo et al. 2005). Additionally, prolonged reproduction indicates that individuals produce several broods during the breeding period or breed asynchronously (Litulo et al. 2005) and that the species presents high genetic tolerance to environmental conditions (Cobo 2002a).

The continuous breeding period of the present population is similar to others of the same species, in low (Moura et al. 2000) and high latitudes (Silva \& Oshiro 2002; Cobo \& Fransozo 2003), even though the reproductive period can vary along a latitudinal gradient (Sastry 1983, Jones \& Simons 1983, Díaz \& Conde 1989, Emmerson 1994, Bryant \& Hartnoll 1995, Lardies et al. 2004, Cobo 2002a, Cobo 2002b, Castiglioni et al. 2007). Factors that are independent of latitude, such as intertidal zonation, can lead to this non-variance of the breeding period. Species that live upper on the shore tend to breed in restricted periods and species living lower on the shore, such as G. cruentata, may present extended breeding activity (Boolootian et al. 1959, Pillay \& Ono 1978, Sastry 1983, Emmerson 1994, Morgan \& Christy 1995, Yamaguchi 2001). 
A

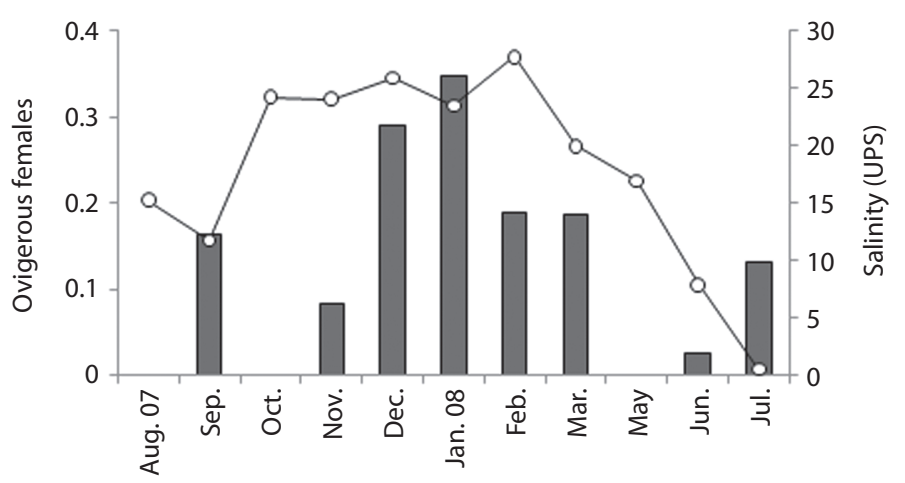

$\varpi$ Ovigerous females* $\multimap-$ Salinity (UPS)

B

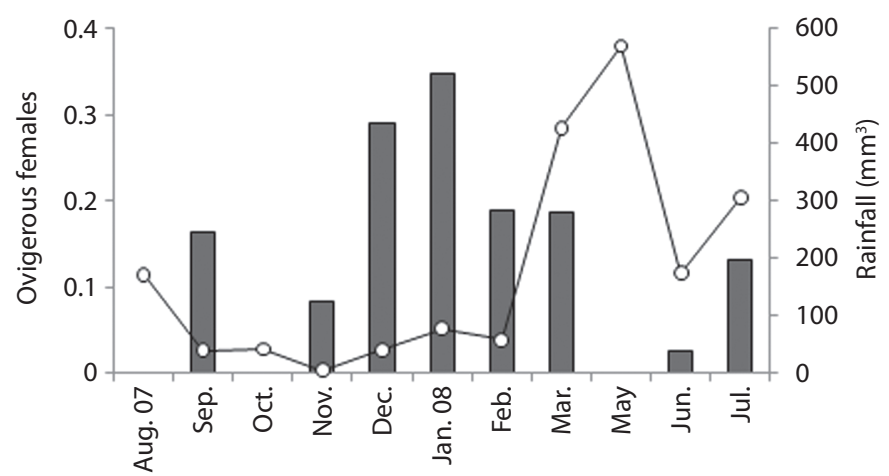

Ovigerous females* $\multimap-$ Rainfall

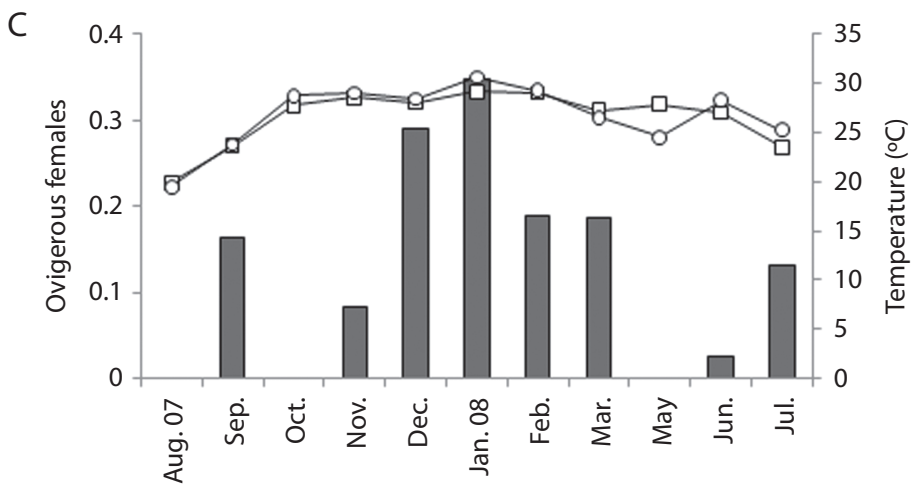

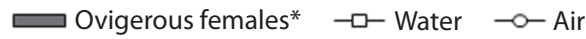

Fig. 2. Correlation between the monthly occurrence of ovigerous females and the monthly mean of (A) salinity, (B) rainfall and $(\mathbf{C})$ air and water temperature. 
The low frequency of egg-bearer females throughout the study period was also observed to this species (Silva \& Oshiro 2002, Cobo \& Fransozo 2003), and is not an uncommon result among brachyuran crabs (Seiple \& Salmon 1987, Mantelatto \& Fransozo 1997, NegreirosFransozo et al. 2002, Pinheiro \& Fransozo 2002, Mantelatto et al. 2003, Lima et al. 2006, Castiglioni et al. 2007, César et al. 2007), what can be due to a cryptic habit of these crabs in relation to the non-ovigerous females. Additional catch effort is totally not recommended since it will cause bias in the determination of the period of breeding activity. Therein, even though one can think that there is a lack of data, it must be the biological pattern of a species, but still offering valuable data for the understanding of the reproduction of the species.

The monthly proportion of ovigerous females was not correlated to any of the analyzed environmental parameters. However, other authors have observed a correlation between the abiotic factors and the abundance of ovigerous females, as Cobo \& Fransozo (2003) for G. cruentata and Castiglioni et al. (2011) for Sesarma rectum Randall, 1840. This difference probably occurs due to the more stable environment conditions in the present area, which may mask their influence on the biological activities in the populations located at lower latitudes.

The higher frequency of ovigerous females observed in the dry period suggests that higher salinity and air and water temperatures, and lower rainfall may promote an intensification of the breeding activity. In fact, there is some empirical evidence that higher salinities favor a shorter period of larval development and improve the larvae survival in the initial stages of development (Saigusa 1981, Álvarez \& Ewald 1990, Anger et al. 1990, Steele \& Steele 1991, Anger et al. 1998, Bas \& Spivak 2000, Gélin et al. 2001, Paula et al. 2001, Spivak \& Cuesta 2009). Therefore, offspring released in the dry period may experience higher survival rates than that released in the rainy period. Water temperature, higher in the dry period, may also provide a shorter larval development
(Emmerson 1994, Paula et al. 2001, Christy 2003). Hence, breeding in periods of both higher salinities and water temperatures may represent a predation avoidance tactic, since larvae is too vulnerable to predation (Emmerson 1994). On the other hand, the sudden elevation of rainfall and a small decrease of the temperature between February and March may have compelled to come back to the ordinary production of eggs after two months, in May (or after one month, in April when no collection was done).

In the case of terrestrial and semi-terrestrial crabs, air temperature is of greater importance than water temperature to the adult life. It acts as a trigger to the gonad development (Wear 1974, Sastry 1983, Zimmerman \& Felder 1991, Lardies et al. 2004), and crabs exposed to low temperatures present a longer embryogenesis, leading to a longer incubation period (Wear 1974, Yamaguchi 2001). A faster gonad development, which may occur in tropical areas due to higher temperatures, enables the crab hatches more than one batch of eggs in the optimal time for egg release, maximizing its reproductive effort (Jones \& Simons 1983, Ituarte et al. 2004). This fact may represent a selective advantage to breed in the dry period.

The breeding period clearly occurs when rainfall was lower, i.e. in the dry period, even though not correlated to the monthly values of rainfall. This data did not corroborate with that of Cobo \& Fransozo (2003) to the same species, in a higher latitude tropical area, when highest proportion of ovigerous females occurred in periods of higher rainfall. In fact, breeding is commonly assumed to be positively correlated with the rainfall (Litulo 2004, Litulo 2005, Liu \& Jeng 2005), when the channels in the estuary are deeper and the larvae reach the sea more easily to complete its development (Saigusa 1981), being less susceptible to predation (Morgan \& Christy 1995). The rainfall increases the flux of river water, enlarging the lading of nutrients to the estuary, favoring the productivity of the phytoplankton (Mallin et al. 1993) and, hence, the larval development. 
Although not measured in the present study, the major food availability (phytoplankton) to the larvae in the summer (dry period the present area), may also favors breeding activity (Boolootian et al. 1959, Sastry 1983, Emmerson 1994, Castiglioni et al. 2007). This higher nutrition source is due to the higher photoperiod in this season (Cobo \& Fransozo 2003, Litulo et al. 2005), which favors phytoplankton productivity. Sunlight is, in fact, a limiting factor to phytoplankton production. However, in the Northeastern Brazil, the photoperiod does not present significant differences among stations of the year (Passavante \& Feitosa 2004). The phytoplankton production is mainly affected by the suspended material on the surface water, higher on the rainy period. It leads to a decrease in the photic layer and, consequently, in the phytoplankton production (Resurreição et al. 1996).

The fourteen ovigerous females incubating eggs in final stage of development in November and December, within the dry period, can indicate that it is, in fact, the most suitable period for larval release. A low occurrence of ovigerous females was observed in the rainy period, indicating that this period, on the other hand, is not so favorable for larval survival. In fact, breeding all over the year may be a strategy to guarantee reproduction during non-favorable environmental conditions (Litulo 2005), what can be considered as a risk-spreading strategy (Stearns 1976). In general, is assumed that the breeding season is timed to reach the best conditions for larval survival and recruitment (Pillay \& Ono 1978, Díaz \& Conde 1989, Cobo 2002a, Cobo 2002b).

Bas \& Spivak (2000), studying species of Grapsids from Argentina, cited that the salinity tolerance of the embryos can vary in different broods of females of the same species. Thus, each female can incubate their eggs in a different occasion, probably in periods similar to that in which their parental female released them. The larvae tolerance to salinity depends on the previous history experienced by the parental female (Bas \& Spivak 2000), and that fact may explain the continuous breeding activity of $G$. cruentata.

We conclude that the breeding period of G. cruentata is seasonal-continuous, being not regulated by temporal fluctuations of air and water temperature, salinity and rainfall. However, the dry period provide the best conditions to breeding activity of this species (higher air and water temperature, higher salinity and lower rainfall). Future researches may focus on the response of physiological characteristics, gametogenesis, incubation period, and on the larval ecology and recruitment pattern to environmental variations for a completely understand of breeding activity.

\section{ACKNOWLEDGMENT}

The authors are thankful to Paulo Cardoso and Cristiane Farrapeira, for their suggestions to this manuscript. The first author is grateful to the Conselho Nacional de Desenvolvimento Científico e Tecnológico-CNPq, for the fellowship granted (process number 112334/2007-5).

\section{RESUMEN}

Los cangrejos Brachyura son especies iteróparas, que presentan alta diversificación en los patrones de reproducción, que pueden haber evolucionado como una respuesta específica de la especie a las condiciones ambientales. Las especies tropicales frecuentemente presentan una reproducción en todo el año debido a las condiciones estables del medio. El cangrejo Goniopsis cruentata es una especie ampliamente distribuida en largo del Atlántico occidental, y que habita prácticamente cada micro-hábitat en el ecosistema de manglar. El objetivo del presente estudio fue evaluar el periodo de reproducción del cangrejo $G$. cruentata en el noreste de Brasil. Un total de 71 hembras ovadas, fueron capturadas entre agosto 2007 y julio 2008, y utilizadas para obtener el periodo de reproducción de esta especie. Nuestra hipótesis es que, ya que las zonas tropicales no presentan gran variación de las temperaturas, las oscilaciones temporales de la salinidad son el principal factor que influye en la actividad reproductiva de $G$. cruentata. Se analizó el período reproductivo mediante la proporción mensual de hembras ovadas. Una correlación fue aplicada para evaluar la influencia de los factores abióticos limitantes (salinidad, pluviosidad, temperatura del aire y del agua) en la época de crianza. La población 
se reproduce continuamente con picos estacionales en el período seco, lo que no fue asociado a las variaciones mensuales de salinidad, precipitación y temperatura del aire y del agua. Por lo tanto, nuestra hipótesis fue refutada. Sin embargo, la reproducción se intensificó en el período seco, cuando la salinidad y las temperaturas fueron más altas y la precipitación fue menor. Se concluye que, a pesar de que la reproducción no está relacionada con la variación mensual de los factores ambientales limitantes, ella ocurre en períodos de mayor salinidad y temperatura, y baja precipitación.

Palabras clave: historia de vida, reproducción, hembras ovadas, parámetros ambientales, manglar.

\section{REFERENCES}

Abele, L.G. \& W. Kim. 1989. The Decapod Crustaceans of the Panama Canal. Smithson. Contrib. Zool. 482: $1-46$.

Adiyodi, R.G. 1988. Reproduction and development, p. 139-185. In W.W. Burggren \& B.R. McMahon (eds.). Biology of the Land Crabs. Cambridge University, Cambridge, United Kingdom.

Álvarez, Z. \& J. Ewald. 1990. Efectos de la salinidad y la dieta sobre el desarrollo larvario de Sesarma ricordi (Milne Edwards, 1853) (Decapoda: Grapsidae). Sci. Mar. 54: 55-60.

Anger, K., J. Harms, M. Montú \& C. Bekker. 1990. Effects of salinity on the larval development of a semiterrestrial tropical crab, Sesarma angustipes (Decapoda: Grapsidae). Mar. Ecol. Prog. Ser. 62: 89-94.

Anger, K., E. Spivak \& T. Luppi. 1998. Effects of reduced salinities on development and bioenergetics of early larval shore crab, Carcinus maenas. J. Exp. Mar. Biol. Ecol. 220: 287-304.

Araújo, M.S.L.C. \& T.C.S. Calado. 2008. Bioecologia do caranguejo-Uçá Ucides cordatus (Linnaeus) no Complexo Estuarino Lagunar Mundaú/Manguaba (CELMM), Alagoas, Brasil. Rev. Gest. Cost. Integr. 8: 169-181.

Bas, C.C. \& E.D. Spivak. 2000. Effect of salinity on embryos of two southeastern atlantic estuarine grapsid crab species cultured in vitro. J. Crustac. Biol. 20; 647-656.

Bell, G. 1976. On Breeding More Than Once. Am. Nat. 110: 57-77.

Boolootian, R.A., A.C. Giese, A. Farmanfarmaian \& J. Tucker. 1959. Reproductive cycles of five west coast crabs. Physiol. Zool. 32: 213-220.

Bryant, D. \& R.G. Hartnoll. 1995. Reproductive investment in two spider crabs with different breeding strategies. J. Exp. Mar. Biol. Ecol. 188: 261-275.
Calado, T.C.S. \& E.C. Sousa. 2003. Crustáceos do Complexo Estuarino/Lagunar Mundaú/ Manguaba, Alagoas. FAPEAL, Maceió, Alagoas, Brazil.

Castiglioni, D.S. \& M.L. Negreiros-Fransozo. 2006. Ciclo reprodutivo do caranguejo violonista Uca rapax (Smith) (Crustacea: Brachyura: Ocypodidae) habitante de um estuário degradado em Paraty, Rio de Janeiro, Brasil. Rev. Bras. Zool. 23: 331-339.

Castiglioni, D.S., M.L. Negreiros-Fransozo \& C.F. Cardoso. 2007. Breeding season and molt cycle of the fiddler crab Uca rapax (Brachyura: Ocypodidae) in a subtropical estuary, Brazil, South America. Gulf. Caribb. Res. 19: 11-20.

Castiglioni, D.S., P.J.A. Oliveira, J.S.S. Silva \& P.A. Coelho. 2011. Population dynamics of Sesarma rectum (Crustacea: Brachyura: Grapsidae) in the Ariquindá River mangrove, North-east of Brazil. J. Mar. Biol. Ass. U.K. 91: 1395-1401.

César, I.I., L.C. Armendariz \& R.V. Becerra. 2007. Fecundity of Uca uruguayensis and Chasmagnathus granulatus (Decapoda, Brachyura) from the "Refúgio de Vida Silvestre", Bahía Samborombón, Argentina. Braz. J. Biol. 67: 749-753.

Christy, J.H. 2003. Reproductive timing and larval dispersal of intertidal crabs: the predator avoidance hypothesis. Rev. Chil. Hist. Nat. 76: 177-185.

Cobo, V.J. 2002a. Breeding period of the arrow crab Stenorhynchus seticornis from Couves Island, southeastern Brazilian coast. J. Mar. Biol. Ass. U.K. 82: 1031-1032.

Cobo, V.J. 2002b. Breeding period of the spider crab Mithraculus forceps (A. Milne Edwards) (Crustacea: Majidae: Mithracinae) in the southeastern Brazilian coast. Rev. Bras. Zool. 19: 229-234.

Cobo, V.J. \& A. Fransozo. 2003. External factors determining breeding season in the red mangrove crab Goniopsis cruentata (Latreille) (Crustacea: Brachyura: Grapsidae) on the São Paulo state northern coast, Brazil. Rev. Bras. Zool. 20: 213-217.

Cole, L.C. 1954. The population consequences of life histories phenomena. Q. Rev. Biol. 29: 103-137.

Díaz, H. \& J.E. Conde. 1989. Population dynamics and life history of the mangrove crab Aratus pisonii (Brachyura: Grapsidae) in a marine environment. Bull. Mar. Sci. 45: 148-163.

Emmerson, W.D. 1994. Seasonal breeding cycles and sex ratios of eight species of crabs from Mgazana, a mangrove estuary in Transkei, Southern Africa. J. Crustac. Biol. 14: 568-578.

Eskinazi-Leça, E. 1976. Taxonomia e distribuição das diatomáceas (Bacillariophyceae) na laguna Mundaú, Alagoas, Brasil. Doctoral Thesis, Federal University of Pernambuco, Recife, Brazil. 
Gadgil, M. \& W.H. Bossert. 1970. Life historical consequences of natural selection. Am. Nat. 104: 1-24.

Gélin, A., A. J. Crivelli, E. Rosecchi \& P. Kerambrun. 2001. Can salinity changes affect reproductive success in the brown shrimp Crangon crangon? J. Crustac. Biol. 21: 905-911.

Hartnoll, R.G. \& P. Gould. 1988. Brachyuran life history strategies and the optimization of egg production, $\mathrm{p}$. 1-9. In A.A Fincham \& P.S. Rainbow (eds.). Aspects of Decapod Crustacean Biology. Clarendon, Oxford, United Kingdom.

Hogarth, P.J. 2007. The Biology of Mangroves and Seagrasses. Oxford University, Oxford, United Kingdom.

Ituarte, R.B., E.D. Spivak \& T.A. Luppi. 2004. Female reproductive cycle of the southwestern Atlantic estuarine crab Chasmagnathus granulatus (Brachyura: Grapsoidea: Varunidae). Sci. Mar. 68: 127-137.

Jones, M.B. \& M.J. Simons. 1983. Latitudinal variation in reproductive characteristics of a mud crab, Helice crassa (Grapsidae). Bull. Mar. Sci. 33: 656-670.

Lardies, M.A., J.M. Rojas \& I.S. Wehrtmann. 2004. Breeding biology and population structure of the intertidal crab Petrolisthes laevigatus (Anomura: Porcellanidae) in central-southern Chile. J. Nat. Hist. 38: 375-388.

Lima, G.V., M.R.S. Soares \& L.M.Y. Oshiro. 2006. Reproductive biology of the sesarmid crab Armases rubripes (Decapoda: Brachyura) from an estuarine area of the Sahy river, Sepetiba Bay, Rio de Janeiro, Brazil. Ilheríngia 96: 47-52.

Litulo, C. 2004. Reproductive aspects of a tropical population of the fiddler crab Uca annulipes (H. Milne Edwards, 1837) (Brachyura: Ocypodidae) at Costa do Sol Mangrove, Maputo Bay, southern Mozambique. Hydrobiologia 525: 167-173.

Litulo, C. 2005. External factors determining the reproductive periodicity in a tropical population of the hairy crab Pilumnus vespertilio (Decapoda: Brachyura: Pilumnidae). Raf. Bull. Zool. 53: 115-118.

Litulo, C., Y. Mahanjane \& F.L.M. Mantelatto. 2005. Population biology and breeding period of the sandbubbler crab Dotilla fenestrata (Brachyura: Ocypodidae) from Southern Mozambique. Aquat. Ecol. 39: 305-313.

Liu, H.C. \& M.S. Jeng. 2005. Reproduction of Epigrapsus notatus (Brachyura: Gecarcinidae) in Taiwan. J. Crustac. Biol. 25: 135-140.

Mallin, M.A., H.W. Paerl, J. Rudek \& P.W. Bates. 1993. Regulation of estuarine primary production by watershed rainfall and river flow. Mar. Ecol. Prog. Ser. 93: 199-203.

Mantelatto, F.L.M. \& A. Fransozo. 1997. Fecundity of the crab Callinectes ornatus Ordway 1863 (Decapoda,
Brachyura, Portunidae) from the Ubatuba region, São Paulo, Brazil. Crustaceana 70: 214-226.

Mantelatto, F.L.M., F.C.R. Faria \& R.B. Garcia. 2003. Biological aspects of Mithraculus forceps (Brachyura: Mithracidae) from Anchieta Island, Ubatuba, Brazil. J. Mar. Biol. Ass. U.K. 83: 789-791.

Marques, J.G.W. 2001. Aspectos ecológicos da etnoictiologia dos pescadores no Complexo Estuarino - Lagunar Mundaú/Manguaba. Doctoral thesis, State University of Campinas, Campinas, Brazil.

Melo, G.A.S. 1996. Manual de identificação dos Brachyura (caranguejos e siris) do litoral brasileiro. FAPESP/ Plêiade, São Paulo, Brazil.

Morgan, S.G. \& J.H. Christy. 1995. Adaptative significance of the timing of larval release by crabs. Am. Nat. 145: 457-479.

Moura, N.F.O., P.A. Coelho-Filho \& P.A. Coelho. 2000. Population structure of Goniopsis cruentata (Latreille 1803 ) in the Paripe estuary, Brazil. Nauplius 8: 73-78.

Negreiros-Fransozo, M.L., A. Fransozo \& G. Bertini. 2002. Reproductive cycle and recruitment period of Ocypode quadrata (Decapoda: Ocypodidae) at a Sandy beach in southeastern Brazil. J. Crustac. Biol. 22: $157-161$.

Okamori, C.M. \& V.J. Cobo. 2003. Fecundity of the arrow crab Stenorhyncus seticornis in the southern Brazilian coast. J. Mar. Biol. Ass. UK 83: 979-980.

Paula, J., R.N. Mendes, S. Paci, P. McLaughlin, F. Gherardi \& W. Emmerson. 2001. Combined effects of temperature and salinity on the larval development of the estuarine mud prawn Upogebia africana (Crustacea: Thalassinidea). Hydrobiologia 449: 141-148.

Passavante, J.Z.O. \& F.A.N. Feitosa. 2004. Dinâmica da Produtividade Fitoplanctônica na Zona Costeira, p. 425-439. In E. Eskinazi-Leça, S. Neumann-Leitão \& M.F. Costa (eds.). Oceanografia: Um Cenário Tropical. Bagaço, Recife, Brazil.

Pillay, K.K. \& Y. Ono. 1978. The breeding cycles of two species of grapsid crabs (Crustacea: Decapoda) from the north coast of Kyushu, Japan. Mar. Biol. 45: 237-248.

Pinheiro, M.A.A. \& A. Fransozo. 2002. Reproduction of the speckled swimming crab Arenaeus cribrarius (Brachyura: Portunidae) on the Brazilian coast near 23ํㅜㅇ'S. J. Crustac. Biol. 22: 416-428.

Resurreição, M.G., J.Z.O. Passavante \& S.J. Macedo. 1996. Estudo da plataforma continental na área do Recife (Brasil): variação sazonal da biomassa fito-

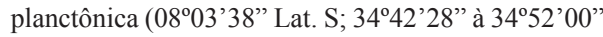
Long. W). Trab. Oceanográficos 24: 39-59.

Ricklefs, R.E. \& M. Wikelski. 2002. The physiology/life history nexus. Trends Ecol. Evol. 17: 462-468. 
Saigusa, M. 1981. Adaptive significance of a semilunar rhythm in the terrestrial crab Sesarma. Biol. Bull. 160: 311-321.

Sastry, A.N. 1983. Ecological aspects of reproduction, p. 179-270. In F.J. Vernberg \& W.B. Vernberg (eds.). The Biology of Crustacea - Environmental Adaptations. Academic, London, United Kingdom.

Seiple, W.H. \& M. Salmon. 1987. Reproductive, growth and life-history between two species of grapsid crabs, Sesarma cinereum and S. reticulatum. Mar. Biol. 94: 1-6.

Silva, Z.S. \& L.M.Y. Oshiro. 2002. Aspectos reprodutivos de Goniopsis cruentata (Latreille) (Crustacea, Brachyura, Grapsidae) na Baía de Sepetiba, Rio de Janeiro, Brasil. Rev. Bras. Zool. 19: 907-914.

Skov, M.W., R.G. Hartnoll, R.K. Ruwa, J.P. Shunula, M. Vannini \& S. Cannici. 2005. Marching to a different drummer: crabs synchronize reproduction to a 14-month-tidal cycle. Ecology 86: 1164-1171.

Spivak, E.D. \& J.A. Cuesta. 2009. The effect of salinity on larval development of Uca tangeri (Eydoux, 1835) (Brachyura: Ocypodidae) and new findings of the zoeal morphology. Sci. Mar. 73: 297-305.

Stearns, S.C. 1976. Life-history tactics: a review of the ideas. Q. Rev. Biol. 51: 3-47.
Stearns, S.C. 2000. Life history evolution: successes, limitations, and prospects. Naturwissenschaften 87 : 476-486.

Steele, D.H. \& V.J. Steele. 1991. Effects of salinity on the survival, growth rate, and reproductive output of Gammarus lawrencianus (Crustacea: Amphipoda). Mar. Ecol. Prog. Ser. 78: 49-56.

Wear, R.G. 1974. Incubation in British decapods Crustacea, and the effects of temperature on the rate and success of embryonic development. J. Mar. Biol. Ass. UK 54: 745-762.

Yamaguchi, T. 2001. The breeding period of the fiddler crab, Uca lactea (Decapoda: Brachyura: Ocypodidae) in Japan. Crustac. Int. J. Crustac. Res. 74: 285-293.

Zar, J.H. 1999. Bioestatistical Analysis. Prentice Hall, New Jersey, USA

Zera, A.J. \& G.L. Harshman. 2001. The physiology of life history trade-offs in animals. Annu. Rev. Ecol. Syst. 32: 95-126.

Zimmerman, T.L. \& D.L. Felder. 1991. Reproductive ecology of an intertidal brachyuran crab, Sesarma sp. (nr. reticulatum), from the Gulf of Mexico. Biol. Bull. 181: $387-401$. 